Kocacaliskan, I., T. Akgul, and S. Erisen, Effect of Juglone on Seed Germination and Seedling Growth of Four Common Vegetables. International Journal of Life Sciences and Biotechnology, 2019. 2(1): p. 4349.

\title{
Effect of Juglone on Seed Germination and Seedling Growth of Four Common Vegetables
}

\author{
İsmail Kocacaliskan*1, Tugce Akgul², Semiha Erisen ${ }^{1}$
}

ABSTRACT

In this study, effect of juglone on seed germination and post-germinative seedling growth of four common vegetables (aubergine, pepper, zucchini and gherkin) has been investigated. Juglone treatments were applied at 0 (control), $0.001,0.01,0.1$ and $1 \mathrm{mM}$ concentrations. Seed germination of aubergine and pepper was significantly inhibited by juglone but in the case of zucchini and gherkin, juglone didn't change the germination of the seeds. However, both root and shoot elongation and dry weights of the seedlings of all the species studied were significantly decreased by juglone above $0.01 \mathrm{mM}$ concentrations with respect to control. The sensitivity range of the species to juglone was determined as aubergine, pepper, zucchini and gherkin, respectively. That is, the most sensitive species to juglone was found aubergine that juglone inhibited its seedling growth at even $0.001 \mathrm{mM}$ concentration.

\author{
ARTICLE HISTORY \\ Received \\ 28 March 2019 \\ Accepted \\ 27 April 2019
}

KEYWORDS

Juglone, germination, seedling growth, aubergine, pepper, zucchini, gherkin

\section{Introduction}

The chemical interactions mainly between plants are named allelopathy. The organic substances playing roles in allelopathy are called allelochemicals. The release of allelochemicals from plants occurs by volatilization, leaching from leaves, exudation from roots and degradation of dead plant parts. Allelochemicals become stressful when they are toxic. Sometimes an allelochemical produced by a plant is harmful to another but beneficial to a third plant species at the same concentration [1-6]. Temperature was the most effective parameter in increasing synthesis and exudation of allelochemicals in plants [7]. The inhibitory effect of walnut on associated plants is one of the oldest examples of allelopathy and dominant allelochemical in walnut allelopathy is juglone (5-hydroxy-1,4 naphthoquinone). Hydrojuglone which is a nontoxic form is abundant in several organs of walnut tree. When exposed to air or to some oxidizing substance hydrojuglone, it is oxidized to its toxic form, juglone [8,9]. Juglone is not only allelopathically important but it also is an important allelochemical in its antiviral [10], antibacterial and antifungal [11-14], antioxidant [15, 16], herbicidal [17], and anticancer [18-21] properties.

\footnotetext{
${ }^{1}$ Molecular Biology and Genetics Department, Yıldız Technic University, İstanbul, Turkey

${ }^{2}$ Graduate School of Natural and Applied Sciences, Y1ld1z Technic University, İstanbul, Turkey

*Corresponding author: ikocacaliskan@gmail.com
} 
It is an agronomic importance to be selecting plant species not sensitive to juglone for planting in the same field with walnut trees. Using this intercropping system is commonly seen in Turkey, as can be seen in several countries on the world. However, the agronomic efficiency of some plant species may be diminished by the detrimental effect of walnut on juglone sensitive species. Although juglone has been shown to increase growth of melon seedlings, it has contrarily been shown to decrease seedling growth of some vegetables such as cress, tomato, cucumber, radish and watermelon. [2].

However, we could not encountered any study about the effect of juglone on aubergine, pepper, zucchini and gherkin in the literature. In addition, these species are common cultivated vegetables on the world. Therefore, in this work, we aimed to reveal if juglone's allelopathic effect is inhibitory or stimulatory on seed germination and seedling growth of these vegetables.

\section{Materials and Methods}

In this work, seeds of aubergine (Solanum melongena cv. Aydın siyahi), pepper (Capsicum annuum cv. Yalova çarliston), zucchini (Cucurbita pepo cv. Sakız) and gherkin (Cucumis flexuosus cv. Acur) were obtained from "Balıkesir Tohumculuk" company/Turkey. The seeds were surface sterilized with $1 \%$ sodium hypochloride. At least 20 seeds were placed in a Petri dish furnished with sheets of filter paper moistened with distilled water (control) or with juglone solutions in the range of $0.001,0.01,0.1$ and $1 \mathrm{mM}$ concentrations, between 4-14 $\mathrm{ml}$ depending on seed size. After the treatments, Petri dishes were keeped in an incubator at $25{ }^{\circ} \mathrm{C}$ in continuous dark for seven days. The germination percentages of the seeds were followed and recorded every day during the incubation. In the last of 7th day, germination rate of the seeds was determined by dividing total germination percentages of the seeds to 7 , then the seedling growth was defined by measuring lengths and weights of the seedlings separated to root and shoot. Each treatment was replicated three times and statistical significance between the means of the treatments was indicated on the Tables at 0.05 level using Duncan's multiple range test. 


\section{Results and Discussion}

Germination rate of the aubergine seeds were significantly decreased by juglone at 0.01 , 0.1 and $1 \mathrm{mM}$ juglone concentrations according to control (Table 1).

Table 1 Effects of juglone on germination of seeds and growth of seedlings in aubergine.

\begin{tabular}{|c|c|c|c|c|c|c|c|}
\hline $\begin{array}{l}\text { Juglone } \\
(\mathbf{m M})\end{array}$ & $\begin{array}{l}\text { Germination } \\
\text { rate }\end{array}$ & $\begin{array}{l}\text { Root } \\
(\mathbf{c m})\end{array}$ & length & $\begin{array}{l}\text { Shoot } \\
\text { (cm) }\end{array}$ & length & $\begin{array}{l}\text { Root dry w. } \\
(\mathbf{m g})\end{array}$ & $\begin{array}{l}\text { Shoot dry w. } \\
\text { (mg) }\end{array}$ \\
\hline 0 (Control) & 66 a & $3.6 \mathrm{a}$ & & $2.9 \mathrm{a}$ & & $2.9 \mathrm{a}$ & $5.7 \mathrm{a}$ \\
\hline 0.001 & $65 \mathrm{a}$ & $2.5 \mathrm{~b}$ & & $1.9 \mathrm{~b}$ & & $2.0 \mathrm{~b}$ & $4.2 \mathrm{~b}$ \\
\hline 0.01 & $51 \mathrm{~b}$ & $2.3 \mathrm{~b}$ & & $1.7 \mathrm{~b}$ & & $1.5 \mathrm{~b}$ & $3.3 \mathrm{~b}$ \\
\hline 0.1 & $49 \mathrm{~b}$ & $2.2 \mathrm{~b}$ & & $1.6 \mathrm{~b}$ & & $0.9 \mathrm{~b}$ & $2.6 \mathrm{~b}$ \\
\hline 1.0 & $0 \mathrm{c}$ & $0 \mathrm{c}$ & & $0 \mathrm{c}$ & & $0 \mathrm{c}$ & $0 \mathrm{c}$ \\
\hline
\end{tabular}

Means with the same letters in each column are not significantly different (Duncan, 5\%); $\mathrm{n}=3$.

Juglone has also decreased germination of the pepper seeds at $1 \mathrm{mM}$ (Table 2). Even 1 $\mathrm{mM}$ juglone has completely inhibited seed germination of these species that germination rate was zero. However, germinations of the zucchini and gherkin seeds were not decreased by juglone in any concentrations (Table 3 and 4).

Table 2 Effects of juglone on germination of seeds and growth of seedlings in pepper.

\begin{tabular}{lllllll}
\hline $\begin{array}{l}\text { Juglone } \\
(\mathbf{m M})\end{array}$ & $\begin{array}{l}\text { Germination } \\
\text { rate }\end{array}$ & $\begin{array}{l}\text { Root } \\
(\mathbf{c m})\end{array}$ & length & $\begin{array}{l}\text { Shoot } \\
(\mathbf{c m})\end{array}$ & length & $\begin{array}{l}\text { Root dry } \\
(\mathbf{m g})\end{array}$ \\
\hline $0($ Control $)$ & $62 \mathrm{a}$ & $4.9 \mathrm{a}$ & $3.1 \mathrm{a}$ & $4.8 \mathrm{a}$ & $\begin{array}{l}\text { Shoot dry w. } \\
(\mathbf{m g})\end{array}$ \\
0.001 & $61 \mathrm{a}$ & $3.5 \mathrm{ab}$ & $2.8 \mathrm{ab}$ & $3.6 \mathrm{ab}$ & $7.5 \mathrm{ab}$ \\
0.01 & $59 \mathrm{a}$ & $3.2 \mathrm{ab}$ & $2.6 \mathrm{ab}$ & $3.0 \mathrm{ab}$ & $6.9 \mathrm{ab}$ \\
0.1 & $56 \mathrm{a}$ & $2.7 \mathrm{~b}$ & $2.3 \mathrm{~b}$ & $2.7 \mathrm{~b}$ & $5.8 \mathrm{~b}$ \\
1.0 & $0 \mathrm{~b}$ & $0 \mathrm{c}$ & $0 \mathrm{c}$ & $0 \mathrm{c}$ & $0 \mathrm{c}$ \\
\hline
\end{tabular}

Means with the same letters in each column are not significantly different (Duncan, 5\%); $\mathrm{n}=3$. 
Table 3 Effects of juglone on germination of seeds and growth of seedlings in zucchini.

\begin{tabular}{lllllll}
\hline $\begin{array}{l}\text { Juglone } \\
(\mathbf{m M})\end{array}$ & $\begin{array}{l}\text { Germination } \\
\text { rate }\end{array}$ & $\begin{array}{l}\text { Root } \\
(\mathbf{c m})\end{array}$ & length & $\begin{array}{l}\text { Shoot } \\
(\mathbf{c m})\end{array}$ & length & $\begin{array}{l}\text { Root dry } \\
(\mathbf{m g})\end{array}$ \\
\hline $0($ Control $)$ & $65 \mathrm{a}$ & $9.3 \mathrm{a}$ & $4.2 \mathrm{a}$ & $30.2 \mathrm{a}$ & $\begin{array}{l}\text { Shoot dry w. } \\
(\mathbf{m g})\end{array}$ \\
0.001 & $60 \mathrm{a}$ & $8.9 \mathrm{a}$ & $3.7 \mathrm{ab}$ & $23.5 \mathrm{ab}$ & $47.8 \mathrm{ab}$ \\
0.01 & $61 \mathrm{a}$ & $8.0 \mathrm{ab}$ & $3.5 \mathrm{ab}$ & $20.4 \mathrm{~b}$ & $39.6 \mathrm{~b}$ \\
0.1 & $65 \mathrm{a}$ & $7.6 \mathrm{ab}$ & $3.4 \mathrm{ab}$ & $17.3 \mathrm{~b}$ & $33.5 \mathrm{~b}$ \\
1.0 & $65 \mathrm{a}$ & $6.2 \mathrm{~b}$ & $3.0 \mathrm{~b}$ & $15.5 \mathrm{~b}$ & $29.4 \mathrm{~b}$ \\
\hline
\end{tabular}

Means with the same letters in each column are not significantly different (Duncan, 5\%); $\mathrm{n}=3$.

Table 4 Effects of juglone on germination of seeds and growth of seedlings in gherkin.

\begin{tabular}{lllllll}
\hline $\begin{array}{l}\text { Juglone } \\
(\mathbf{m M})\end{array}$ & $\begin{array}{l}\text { Germination } \\
\text { rate }\end{array}$ & $\begin{array}{l}\text { Root } \\
(\mathbf{c m})\end{array}$ & length & $\begin{array}{l}\text { Shoot } \\
(\mathbf{c m})\end{array}$ & length & $\begin{array}{l}\text { Root dry } \\
(\mathbf{m g})\end{array}$ \\
\hline $0($ Control $)$ & $65 \mathrm{a}$ & $8.1 \mathrm{a}$ & $5.8 \mathrm{a}$ & $37.6 \mathrm{a}$ & $\begin{array}{l}\text { Shoot dry w. } \\
(\mathbf{m g})\end{array}$ \\
0.001 & $61 \mathrm{a}$ & $7.7 \mathrm{ab}$ & $5.0 \mathrm{ab}$ & $33.1 \mathrm{ab}$ & $35.5 \mathrm{a}$ \\
0.01 & $61 \mathrm{a}$ & $7.8 \mathrm{ab}$ & $4.8 \mathrm{ab}$ & $30.2 \mathrm{~b}$ & $24.2 \mathrm{~b}$ \\
0.1 & $64 \mathrm{a}$ & $6.6 \mathrm{ab}$ & $4.5 \mathrm{ab}$ & $28.6 \mathrm{~b}$ & $20.6 \mathrm{~b}$ \\
1.0 & $61 \mathrm{a}$ & $5.9 \mathrm{~b}$ & $4.1 \mathrm{~b}$ & $25.3 \mathrm{~b}$ & $17.9 \mathrm{~b}$ \\
\hline
\end{tabular}

Means with the same letters in each column are not significantly different (Duncan, 5\%); $n=3$.

In previous studies, it has been shown that juglone's inhibitory effect was on seedling growth rather than seed germination. For example, $1 \mathrm{mM}$ juglone had only decreased seed germination of four species (cress, tomato, cucumber and alfalfa) among 11 plant species studied. But root and shoot elongation of all of the species studied were decreased by juglone, except muskmelon [2]. As seen in Table 1, with respect to control both elongation and dry weight of root and shoot of the aubergine were decreased by all the juglone concentrations. In the case of pepper, while 0.1 and $1 \mathrm{mM}$ juglone concentrations were found to decrease elongation and dry weights of the seedlings, the lower concentrations did not show a significant decrease in the growth parameters 
(Table 2). On the other hand, although root and shoot elongation of zucchini and gherkin were significantly decreased only by $1 \mathrm{mM}$ juglone, their root and shoot dry weights were decreased by $0.01,0.1$ and $1 \mathrm{mM}$ juglone concentrations according to control (Table 3 and 4). Therefore, it may be said that seedling dry weight of zucchini and gherkin were effected by juglone more than their seedling elongation. Formerly, it has been shown that juglone affects plant growth depending on species and concentration. In this study, aubergine and pepper were found more sensitive to juglone than zucchini and gherkin. The reason of this may be sourced from the difference of family that aubergine and pepper are belong to Solanaceae, whereas zucchini and gherkin are belong to Cucurbitaceae family. Generally, juglone in higher concentrations than $0.01 \mathrm{mM}$ shows phytotoxic effect depending on plant species [23] But lower concentrations of juglone than this level may show stimulatory effect or no effect on plant growth [2, 9, 22-25]. Formerly, elongation and dry weight of the root were found less effected than the shoot by juglone in sixteen plant species [23]. However, in our study, juglon did not show a different effect on the elongation and dry weight of root and shoot in the four species studied, as previously mentioned by Kocaçalışkan and Terzi (2001) in eleven plant species.

Plant growth reducing effect of juglone is known to be common. But no information was available about the juglone's allelopathic effect on four plant species studied in this work. Although the species were seen to be decreased their germination and seedling growth by juglone, there were differences between the species in juglone tolerance. The tolerance range of the species to juglone can be aligned as zucchini, pepper and aubergine. That is, the most sensitive species to juglone was aubergine that even 0.001 $\mathrm{mM}$ juglone inhibited its seedling growth. Juglone is exuded from walnut trees and accumulated in canopy soil of walnut about $0.1 \mathrm{mM}$ but rarely it reach to $1 \mathrm{mM}$ concentration depending on species, season and distance from trunk of walnut [23, 26, 27]. Thus, this study revealed that the species studied, especially aubergine and pepper, are not advisable cultivating in a walnut garden because of the juglone phytotoxicity. 


\section{References}

1. Rizvi, S.J.H. and V. Rizvi, Allelopathy. 1992, New York: Chapman and Hall.

2. Kocacaliskan, I. and I. Terzi, Allelopathic effects of walnut leaf extracts and juglone on seed germination and seedling growth. The Journal of Horticultural Science and Biotechnology, 2001. 76(4): p. 436-440.

3. Kocaçalişkan, İ., Allelopati. 2006, Ankara, Turkey: Bizim Büro Press-In Turkish,.

4. Cheema, Z.A. and M.F. Abdulwahid, Alleloptahy: Current trends and future applications. 2013, Berlin, Heidelberg: Springer-verlag.

5. Reigosa, M.J., N. Pedrol, and L. González, Allelopathy A Physiological Process with Ecological Implications. 2006, Springer, Neteherland.

6. $\quad$ Rice, E.L., Allelopathy. 1984, New York: 2nd Edition, Academic Press

7. Pramanik, M.H.R., et al., Effect of temperature amd photoperiod on phytotoxic root exudates of cucumber (Cucumis sativus) in hydroponic culture. J. Chem. Ecol., 2000(26): p. 1953-1967.

8. Lee, K.C. and R.W. Campbell, Nature and occurrence of juglone in Juglans nigra L. . Hort Sci., 1969(4): p. 297-298.

9. Segura-Aguilar, J., I. Hakman, and J. Rydström, The effect of 5OH-1, 4-naphthoquinone on Norway spruce seeds during germination. Plant Physiology, 1992. 100(4): p. 1955-1961.

10. Montenegro, R.C., et al., Cytotoxic activity of naphtoquinones with special emphasis on juglone and its 5-o-methyl derivative. Chemico-Biol. Interactions, 2010, 184(3): p. 439-448.

11. Clark, A.M., T.M. Jurgens, and C.D. Hufford, Antimicrobial activity of juglone. Phytotherapy Research, 1990. 4(1): p. 11-14.

12. Arasoglu, T., et al., Synthesis, characterization and antibacterial activity of juglone encapsulated PLGA nanoparticles. Journal of applied microbiology, 2017. 123(6): p. 1407-1419.

13. Arasoglu, T., et al., Enhancement of Antifungal Activity of Juglone (5-Hydroxy-1, 4naphthoquinone) Using a Poly (d, l-lactic-co-glycolic acid)(PLGA) Nanoparticle System. Journal of agricultural and food chemistry, 2016. 64(38): p. 7087-7094.

14. Kocaçalişkan, İ., et al., Varietal differences in antimicrobial activities of walnut (Juglans regia L.) leaf extracts. Gaziosmanpasa J. Sci. Res. , 2018, 7(3): p. 173-180.

15. Chobot, V. and F. Hadacek, Milieu-dependent pro-and antioxidant activity of juglone may explain linear and nonlinear effects on seedling development. Journal of chemical ecology, 2009. 35(3): p. 383-390.

16. Altikat, S., et al., Allelopathic effects of juglone on growth of cucumber and muskmelon seedlings with respect to antioxidant enzyme activities and lipid peroxidation. Journal of Environmental Protection and Ecology, 2013. 14(3 A): p. 1244-1253.

17. Topal, S., et al., Herbicidal effects of juglone as an allelochemical. Phyton, 2007. 46(2): p. 259269.

18. Sugie, S., et al., Inhibitory effects of plumbagin and juglone on azoxymethane-induced intestinal carcinogenesis in rats. Cancer letters, 1998. 127(1-2): p. 177-183.

19. Aithal, K.B., et al., Juglone, a naphthoquinone from walnut, exerts cytotoxic and genotoxic effects against cultured melanoma tumor cells. Cell biology international, 2009. 33(10): p. 10391049.

20. Xu, H., et al., Juglone, isolated from Juglans mandshurica Maxim, induces apoptosis via downregulation of AR expression in human prostate cancer LNCaP cells. Bioorganic \& medicinal chemistry letters, 2013. 23(12): p. 3631-3634.

21. Xu, H.-L., et al., Anti-proliferative effect of Juglone from Juglans mandshurica Maxim on human leukemia cell HL-60 by inducing apoptosis through the mitochondria-dependent pathway. European Journal of Pharmacology, 2010. 645(1): p. 14-22.

22. Whittaker, R.H. and P.P. Feeny, Allelochemics: chemical interactions between species. Science, 1971. 171: p. 757-770. 
23. Rietveld, W.J., Allelopathic effects of Juglone on germination and growth of several herbaceous and woody species. J. Chem. Ecol., 1983(9): p. 295 - 308.

24. Terz1, I., Allelopathic effects of juglone and walnut leaf and fruit hull extracts on seed germination and seedling growth in muskmelon and cucumber. Asian Journal of Chemistry, 2009. 21(3): p. 1840-1846.

25. Akin, B. and I. Kocacaliskan. Effect of Juglone on Seed Germination and Seedling Growth of Endemic Species Aubrieta olympica and Arabis drabiformis in Tissue Culture Conditions. Phyton-Annales Rei Botanicae. 2016, 56(1): p. 121-128.

26. Ponder, F. and S.H. Tadros, Juglone concentration in soil beneath black walnut interplanted with nitrogen fixing species. J. Chem. Ecol., 1985, 11(7): p. 937-942.

27. Jose, S. and A.R. Gillespie, Allelopathy in black walnut (Juglans nigra L.) alley cropping. I. Spatio-temporal variation in soil juglone in a black walnut-corn (Zea maysL.) alley cropping system in the midwestern USA. Plant and Soil, 1998. 203(2): p. 191-197. 